\title{
An unexpected rise in cardiac troponin I in a patient with multiple myeloma
}

\author{
Olivia Domanski, ${ }^{1}$ Sylvestre Maréchaux, ${ }^{1}$ Gerard Forzy, ${ }^{2}$ Jean-Michel Lemahieu ${ }^{1}$
}

${ }^{1}$ Department of Cardiology, Groupement Hospitalier de I'Institut Catholique de Lille/ Faculté libre de médecine, Lomme, France

${ }^{2}$ Department of Biochemistry, Groupement Hospitalier de I'Institut Catholique de Lille/ Faculté libre de médecine, Lomme, France

\section{Correspondence to}

Dr Sylvestre Maréchaux, sylvestre.marechaux@yahoo.fr

\section{DESCRIPTION}

A 62-year-old patient was admitted to our department for fatigue and chest discomfort. He had a history of multiple myeloma and systemic hypertension. Blood pressure, heart rate and physical examination were unremarkable. ECG demonstrated a normal sinus rhythm with a right bundle branch block (figure 1). Blood was sampled and cardiac troponin (cTn) I was persistently increased from 2.8 to $3 \mathrm{ng} / \mathrm{ml}$ (Beckman Coulter Access II and DXi 800 platforms, Beckman Coulter Inc,
Fullerton, California, USA). Left ventricular ejection fraction was normal at 0.60 with a trace of aortic regurgitation at transthoracic Doppler echocardiography. Coronary angiography revealed the absence of significant luminal narrowing on epicardial arteries (figure $2 \mathrm{~A}, \mathrm{~B}$ ). A monoclonal peak of $\mathrm{IgG}$ was found at serum protein electrophoresis (figure 3). Rheumatoid factor was undetectable. Alanine aminotransferase and aspartate aminotransferase or amylase levels were within the normal range. No fibrin clot was present in the blood

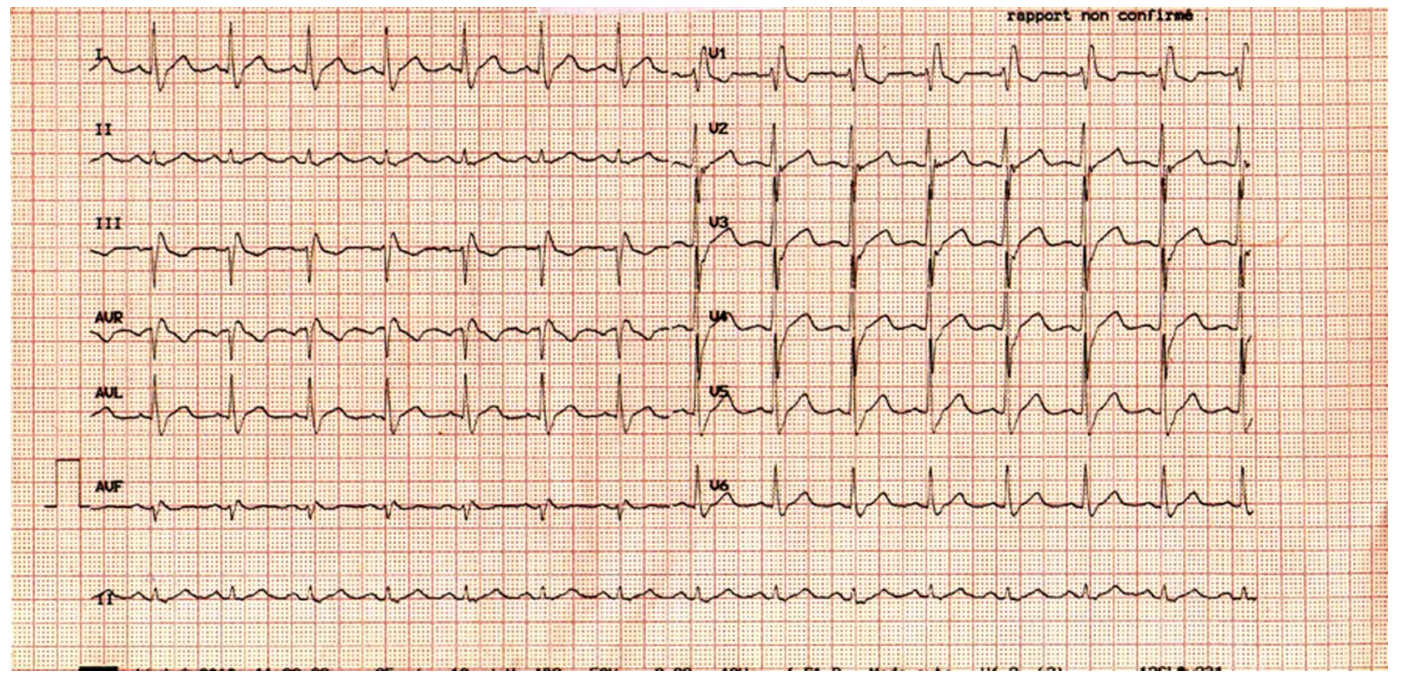

Figure 1 Twelve lead surface ECG demonstrating a right bundle branch block.

To cite: Domanski 0 , Maréchaux S, Forzy G, et al. BMJ Case Reports Published online: 14 December 2012 doi:10.1136/bcr-2012006222
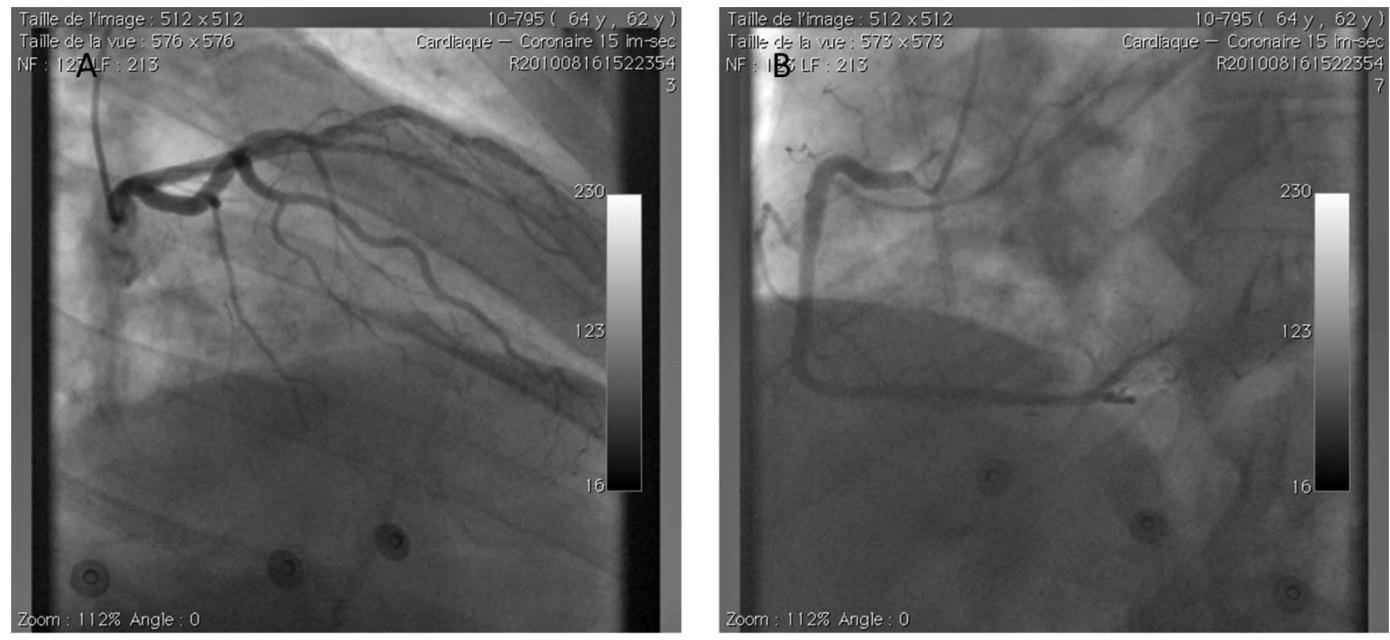

Figure 2 Coronary angiography showing absence of coronary artery narrowing in left (A) and right (B) coronary arteries. 
Figure 3 Serum protein

electrophoresis showing a monoclonal peak of IgG lambda at $11.9 \mathrm{~g} / \mathrm{dl}$.
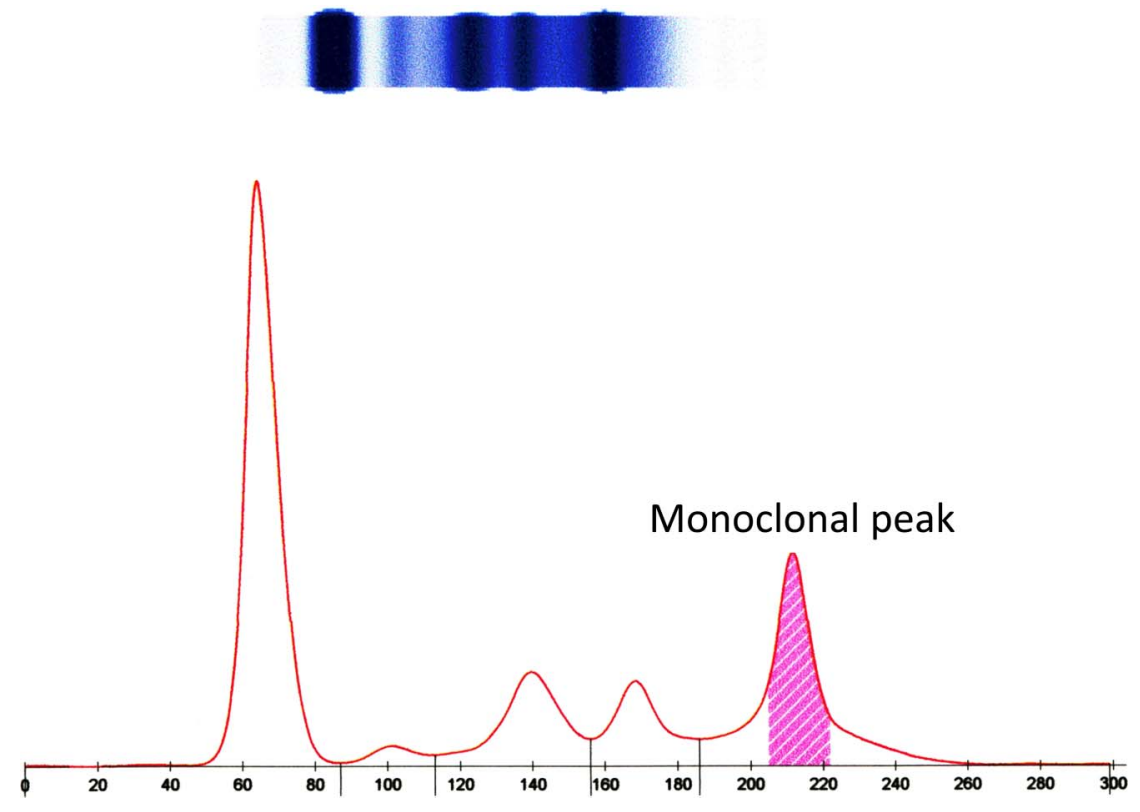

sample and the blood was not apparently viscous. The lipemic index was low at 1 (range from 1 to 15 ) and there was no haemolysis. Serum of the patient was hence mixed with an equal proportion of polyethylene glycol (PEG) 6000, $250 \mathrm{~g} / \mathrm{l}$. The solution was incubated at $37^{\circ} \mathrm{C}$ during $10 \mathrm{~min}$, then centrifuged $10 \mathrm{~min}$ at $5000 \mathrm{rpm}$. cTnI activity was reassessed within the supernatant and remained undetectable.

An unexpected rise in cTnI may occur in various clinical settings other than coronary artery disease, such as pulmonary embolism, sepsis or stress-induced cardiomyopathy. In the present case, the unexpected rise in serum cTnI disappeared after PEG precipitation. Elevated cTnI concentration was attributed to cTnI being sequestered as a high molecular mass (macro) enzyme complex with serum IgG rather than a result of increased cTnI released by damaged myocardial tissue. ${ }^{1}$ Hence, clinicians should pay attention to immunocomplexes involving cTnI and proteins as IgG producing false-positive cTnI in patients with mutiple myeloma. We acknowledge that PEG precipitation has some pitfalls ${ }^{2}$ and does not specifically remove macro cTnI. In addition, PEG precipitation does not identify the mechanism of the interaction between the monoclonal peak and cTnI. In addition, we did not demonstrate in the present case cTnI removal by protein $A$, protein $G$ or antihuman immunoglobulin, ${ }^{3}$ as the clinical course of the patient including normal coronary angiography, did not motivate us to perform additional analyses. Nevertheless, PEG precipitation of IgG followed by other confirmatory techniques may help unveil the absence of 'true' increased serum cTnI concentration and avoid invasive procedures that may be harmful in these frail patients.

\section{Learning points}

- Increased serum cTnl concentration does not always reflect myocardial injury.

- Elevated cTnl concentration may be related to cTnl being sequestered as a high molecular mass (macro) enzyme complex with serum lgG in patients with mutiple myeloma.

- Polyethylene glycol precipitation of IgG followed by other confirmatory techniques may help unveil the absence of 'true' increased serum cTnl concentration in these patients.

Competing interests None.

Patient consent Obtained.

\section{REFERENCES}

1 Plebani M, Mion M, Altinier $\mathrm{S}$, et al. False-positive troponin I attributed to a macrocomplex. Clin Chem 2002;48:677-9.

2 Fahie-Wilson M, Halsall D. Polyethylene glycol precipitation: proceed with care. Ann Clin Biochem 2008;45:233-5.

3 Legendre-Bazydlo LA, Haverstick DM, Kennedy JL, et al. Persistent increase of cardiac troponin I in plasma without evidence of cardiac injury. Clin Chem 2010;56:702-5.

Copyright 2012 BMJ Publishing Group. All rights reserved. For permission to reuse any of this content visit http://group.bmj.com/group/rights-licensing/permissions.

BMJ Case Report Fellows may re-use this article for personal use and teaching without any further permission.

Become a Fellow of BMJ Case Reports today and you can:

- Submit as many cases as you like

- Enjoy fast sympathetic peer review and rapid publication of accepted articles

- Access all the published articles

- Re-use any of the published material for personal use and teaching without further permission

For information on Institutional Fellowships contact consortiasales@bmjgroup.com

Visit casereports.bmj.com for more articles like this and to become a Fellow 